\title{
THE ROLE OF SLMYB GENE IN TOMATO FRUIT DEVELOPMENT
}

\author{
Abdallah A. Hassanin ", S.S.A. Soliman, T.A. Ismail and M.K.A. Amin \\ Genet. Dept., Fac. Agric., Zagazig Univ., Egypt
}

Received: 19/02/2017 ; Accepted: 21/03/2017

\begin{abstract}
The transcription factors regulate the levels of RNA and protein through various processes. Fruit set and fruit development are key process in the life cycle of plants. Fruits provide a suitable environment for the development of seeds and often contribute in the efficient dispersal of mature seeds and also have a high economic impact on the agricultural point of view. The present study aims to characterize the function of SIMYB (Solanum lycopersicum MYB) as a candidate gene involved in fruit set process. To achieve that, various methods and techniques were used in this study like in silico analysis, cytolocalization analysis, qPCR , in situ hybridization and plant transformation. Results from in silico analysis showed that the deduced protein has 195 amino acids with a conserved MYB DNA-binding domain composed of two conserved repeat (R2R3) characteristic of plant transcription factors. Cytolocalization analysis showed that SIMYB protein was localized in the nucleus and cytoplasm. qPCR results showed that SIMYB gene is expressed only in the reproductive tissues, where the highest level of expression occurs in pollinated flowers. qPCR and in situ hybridization results showed that the transcript of SIMYB gene was mainly found in the stamens and ovaries, suggesting that SIMYB may be involved in pollination process and ovary development. To clarify the role of SIMYB gene, gain of function experiment were done by the production of transgenic plants contain the gene of interest overexpressed, characterization of the third generation of transgenic plants showed that the overexpression of the SIMYB gene led to the production of fruit with a large number of seeds. Conversely, silencing of SIMYB gene was done by using virus-induced gene silencing (VIGS) methodology and the silencing led to the reduction of fruit set percentage 13.4\%:35.1\% in silenced plants and $61.25 \%$ in control plants and the production of low number of fruits with very low number of seeds compared to the control plants. To confirm the result of silencing, RNAi methodology was used and the results also showed that the silencing of SIMYB gene led to the reduction of pollen grain fertility and ovary development consequently leading to prevention of fruit set and fruit development. It has been concluded that this gene may involve in flower development and seed formation.
\end{abstract}

Key words: Fruit development, tomato, MYB genes.

\section{INTRODUCTION}

Plant MYBs regulate cell differentiation, organ formation, leaf morphogenesis, secondary metabolism and abiotic stress responses (Ambawat et al., 2013; Qi et al., 2015; Sun et al., 2015; Xu et al., 2015). The function of transcription factors is regulated at the RNA and protein levels through various processes, such as transcriptional regulation, post-transcriptional regulation, post-translational modifications, protein-protein interactions, and controlled

\footnotetext{
* Corresponding author: Tel. : +201024005401

E-mail address: Dr.abdallah4@gmail.com
}

protein turnover (Behm-Ansmant et al., 2006; Spoel et al., 2010).

A lot of studies were carried out on tomato fruit development and ripening. The results of those studies led to the identification of specific genes encoding for transcription factors. MADS (MCM1, AGAMOUS, DEFICIENS, SRF) box transcription factors play important roles in the development of higher eukaryotes. Previous investigations has confirmed that MADS box genes play an important role in the regulation of plant development (Itkin et al., 2009; Klee and 
Giovannoni, 2011; Bemer et al., 2012; Seymour et al., 2013; Fujisawa et al., 2014). The RIN (Ripening-Inhibitor), CNR (clear non-ripening), and NOR (non-ripening) genes have been shown to encode transcriptional regulators and thus likely act to regulate the expression of other genes responsible for ripening phenotypes, including ethylene production (Vrebalov et al., 2002; Giovannoni, 2004; Manning et al., 2006). Other ripening transcriptional regulators have recently been identified via transcriptional profiling studies (Alba et al., 2005) and interaction with ethylene synthesis promoters (Lin et al., 2008). Functional studies demonstrated the critical roles of the TAGL1 transcription factor in both early fleshy fruit expansion and later ripening (Itkin et al., 2009; Vrebalov et al., 2009; Pan et al., 2010).

Furthermore, as a negative regulator of maturation of the fruit is SlAP2a that is one of APETALA2/ERF gene family (ethylene responsive element binding protein), loss of function of this gene producing a high yield of ethylene and alters the accumulation of carotenoids (Chung et al., 2010; Dong et al., 2013). Also IAA9 gene has been identified to encode transcriptional repressor of auxin signaling and is a key mediator in fruit set that belongs to the family of proteins Aux/IAA (Wang et al., 2005).

DELLA proteins are conserved repressors of GA signaling that act immediately downstream of the GA receptor to modulate all aspects of GA-induced growth and development in plants (Thomas and Sun, 2004; Griffiths et al., 2006). Recent studies further suggest that DELLA proteins may also restrict plant growth by integrating signals from other hormone pathway and environmental cues (Achard et al., 2003; $\mathrm{Fu}$ and Harberd, 2003). GA-induced vegetative growth and floral initiation are repressed by RGA and GAI (Dill and Sun, 2001; King et al., 2001). GA-promoted seed germination is mainly regulated by RGL2, although the remaining DELLA genes also play a minor role (Lee et al., 2002; Wen and Chang, 2002; Tyler et al., 2004; Cao et al., 2005; Tyler, 2006). In addition, RGA, RGL1, and RGL2 are involved in flower and fruit development ( $\mathrm{Yu}$ et al., 2000; Cheng et al., 2004; Tyler et al., 2004).
The first gene encoding a transcription factor in plants was identified; the COLORED1 (C1) locus was found to encode a MYB domain protein required for the synthesis of anthocyanins in the aleurone of maize (Zea mays) kernels (Paz-Ares et al., 1987). The functions of MYB proteins have been investigated in numerous plant species such as arabidopsis, maize, rice (Oryza sativa), petunia (Petunia hybrida), snapdragon (Antirrhinum majus), grapevine (Vitis vinifera L.), poplar (Populus tremuloides) and apple (Malus domestica), using both genetic and molecular analyses. A few number of MYB genes have been studied in tomato e.g. Lefsm1 (Rivka et al., 2005) that is expressed specifically during early stages of fruit development and the tomato Blind gene that encodes a MYB transcription factor that controls the formation of lateral meristems (Schmitz et al., 2001).

\section{MATERIALS AND METHODS}

Molecular and expression studies in this work were done in the Institute of Molecular and Cellular Biology of Plants, University of Polytechnique of Valencia, Spain, the statistical analysis and characterization of the $2^{\text {nd }}$ and $3^{\text {rd }}$ generations of transgenic plants were done in Department of Genetics, Faculty of Agriculture, Zagazig University, also the $4^{\text {th }}$ generation was cultured to confirm the obtained results.

\section{Plant Material and Growth Conditions}

Tomato (Solanum lycopersicum L.) cultivar Micro-Tom was used in this study. The plants were grown in the greenhouse $\left(24 \pm 2^{\circ} \mathrm{C}\right.$ day and $20 \pm 2^{\circ} \mathrm{C}$ night), using pots of $17 \mathrm{~cm}$ diameter filled by coconut fiber. Irrigation with nutrient solution was performed twice every day. The relative humidity ranged from $45-65 \%$ during the day and $75-90 \%$ at night. To maintain a long-day photoperiod the natural light was supplemented with artificial light by mercury vapor lamps of $400 \mathrm{w}$.

\section{Nucleic Acids Purification \\ Extraction of plasmid DNA}

For extraction of plasmid DNA $3 \mathrm{ml}$ of overnight culture grown in LB medium supplemented with antibiotic has been used. 
Subsequently following the protocol established for extracting and purifying plasmid DNA of the system Rapid Plasmid System ${ }^{\circledR}$ of Marligen Biosciences, Inc.

\section{Extraction of genomic DNA}

Genomic DNA extraction was performed from young leaves (200-300 mg). The leaves were crushed in $500 \mu \mathrm{L}$ of extraction buffer $(0.2$ M Tris-HCL pH 9.0, $0.4 \mathrm{M} \mathrm{LiCl}, 25 \mathrm{mM}$ EDTA, $1 \% V / V$ SDS) and after centrifugation for 5 minutes at $13,000 \mathrm{rpm}, 350 \mu \mathrm{l}$ of supernatant were transferred to an Eppendorf tube containing $350 \quad 1$ of isopropanol (unpublished method). The mixture was centrifuged for $10 \mathrm{~min}$. The supernatant was removed and the pellet was washed with $70 \%$ ethanol $(V / V) 2$ times. The pellet was allowed to dry and resuspended in $200 \mu 1$ of distilled water. Quantification was performed using the NanoDrop spectrophotometer ${ }^{\circledR}$ ND-1000.

\section{Extraction of total RNA}

Total RNA was isolated from $100 \mathrm{mg}$ of plant tissue using the RNeasy Plant Mini Kit (Qiagen) following the manufacturer's instructions. The RNA was quantified by using a spectrophotometer NanoDrop ${ }^{\circledR}$ ND-1000 at $260 \mathrm{~nm}$. Subsequently the extracted RNA was used for synthesis of cDNA needed for both real-time quantitative $\mathrm{PCR}$ and reverse transcription PCR.

\section{Amplification of DNA by polymerase chain reaction $(\mathrm{PCR})$}

The polymerase chain reaction (PCR) was used to detect the presence of nptII marker gene in transgenic tomato plants from genomic DNA and to isolate different cDNA fragments of SIMYB gene. The amplification reactions were performed in a total volume of $25 \mu 1$, from $50 \mathrm{ng}$ of genomic DNA or $5 \mu \mathrm{l}$ of cDNA in the case of isolation of SIMYB gene. The reaction mixture contained $0.4 \mu \mathrm{M}$ of each of the specific oligonucleotides, $5 \mu \mathrm{l}$ of $2 \mathrm{mM}$ dNTPs, $5 \mu \mathrm{l}$ of $10 \mathrm{X}$ reaction buffer, $1.5 \mu \mathrm{l}$ of $50 \mathrm{mM} \mathrm{MgCl} 2$ and 1.25 units of DNA polymerase (Biotools $\AA$ ). The reactions were run in a Perkin Elmer 2400. The thermocycling conditions used were $95^{\circ} \mathrm{C} 2$ min $+30-35$ cycles $\left(95^{\circ} \mathrm{C} 30 \mathrm{sec},(\mathrm{T})^{\circ} \mathrm{C} 30 \mathrm{sec}\right.$., $\left.72^{\circ} \mathrm{C} 2 \mathrm{~min}\right)+72^{\circ} \mathrm{C} 5 \mathrm{~min}$. In each reaction the annealing temperature $(\mathrm{T})$ was estimated based on the Tm (estimated melting temperature) of the oligonucleotides. The extension time depends on the length of the amplified fragment, generally used $1 \mathrm{~min}$ per $\mathrm{kb}$ of expected product.

\section{Expression Studies}

\section{Quantitative real time polymerase chain reaction (qRT-PCR)}

Experiments of quantitative real time polymerase chain reaction (qRT-PCR) were conducted to analyze gene expression. Oligonucleotides (forward 5'-GGACACTAATT TTCAAGCCTCAAATT-3' and reverse 5'CATGTTGTCATTTGTTTCATTGAGAA-3') were designed using Primer Express v. 2.0 program (Applied Biosystems ${ }^{\mathrm{TM}}$ ) taking a small region of 3 ' end of the gene.

Two $\mu \mathrm{g}$ of total RNA previously treated for 30 min with DNase (Turbo DNA-free from Fermentas ${ }^{\mathrm{TM}}$ ), were used for cDNA synthesis following the manufacturer's recommendations of the system Prime Script RT reagent kit ${ }^{\circledR}$ (TaKaRa). This system is based on the action of a reverse transcriptase MMLV (Moloney Murine Leukemia Virus) and an oligo (dT) was used as primer.

In the analysis ACTINA8 (SlACT8) (MartinTrillo et al., 2011), was used as endogenous gene whose expression is constant in all analyzed tissues by using specific primers (forward 5'-CAA GTT ATT ACC ATT GGT GCT-3' and reverse 5'-TGC AGC TTC CAT ACC AAT CAT-3'). Ct comparative calculation is valid when the amplification efficiency of the gene of interest and the endogenous gene was similar. In all gene expression assays the amplification efficiency was between 90 to $100 \%$.

\section{In situ hybridization}

Labeled probes were synthesized from a cDNA fragment of $290 \mathrm{bp}$ of the gene SIMYB cloned into the vector $\mathrm{pCR} 8 / \mathrm{GW} / \mathrm{TOPO} \mathrm{TA}$ (Invitrogen ${ }^{\mathrm{TM}}$, USA). The fragments were amplified by PCR with oligonucleotides specific to the vector M13 (forward 5'- GTAAAACGA CGGCCAGT-3' and reverse 5'- AACAGCTA TGACCATG $-3^{\prime}$ ) and then purified from a $1 \%$ agarose gel and used as templates for each probe. Probe was transcribed in "antisense" 
respect to the $\mathrm{T} 7$ promoter of the vector, and a "sense" probe was generated as a negative control against nonspecific hybridization.

Flowers were taken in early stages of development, before anthesis, and were immersed in a fixing solution of paraformaldehyde $4 \%$ in $0.1 \mathrm{M}$ phosphate buffer, pH7.2 containing Triton X-100 (0.1\%). Three vacuum pulses of 5 minutes each were used to assist penetration of the fixing solution, then the fixing solution was changed by fresh one and kept at $4{ }^{\circ} \mathrm{C}$ for 16 hours followed by dehydration steps and subsequent embedding in Jung Historesin (Leica). Histological sections of $8 \mu \mathrm{m}$ thickness were made using a Microm microtome HM330, and then placed on slides treated with poly-1-lysine sections on slides were deparaffinized by treating with Histo-Clear ${ }^{\mathbb{R}}$, then rehydrated and washed. For hybridization, $50 \mu \mathrm{l}$ of probes diluted in hybridization buffer were placed on each slide and then slides are covered and incubated overnight in a moist chamber at $50^{\circ} \mathrm{C}$. After hybridization slides were washed and then incubated with antiDioxigenin-AP, Fab fragments Roche ${ }^{\circledR}$ followed by detection buffer which has been replaced by $50 \mathrm{ml}$ of detection buffer containing the substrate $(75 \mu \mathrm{l}$ of NBT $(100 \mathrm{mg} / \mathrm{ml})$ and $75 \mu \mathrm{l}$ of BCIP $(50 \mathrm{mg} / \mathrm{ml})$ from Roche $\left.{ }^{\circledR}\right)$, incubation in darkness longer than $48 \mathrm{hr}$., until the signal was observed. Finally the reaction was stopped by changing the detection solution with water. The samples were dried, mounted with Merckglass (Merck ${ }^{\circledR}$ ) and visualized under microscope.

\section{Virus-induced gene silencing (VIGS)}

Tomato plants used for silencing experiments should be around 7-8 days old when the true leaves have not yet appeared. $1 \mu \mathrm{l}$ from the glycerol stock of Agrobacterium tumefaciens (strain C-58) harboring pTRV1, pTRV2-PDS and pTRV2-host target gene was grown in LB liquid medium supplemented with $100 \mu \mathrm{g} / \mathrm{ml}$ of kanamycin and $100 \mu \mathrm{g} / \mathrm{ml}$ of rifampicin and incubated with shaking at $28^{\circ} \mathrm{C}$ for 2 days. The kanamycin selects for the pTRV plasmid while the rifampicin selects for the Agrobacterium. Silencing of PDS will cause the plants to photobleach and is used as a control for silencing efficiency. After 2 days $100 \mu 1$ of each preculture was transferred to a new $5 \mathrm{ml}$ LB liquid medium with the previous mentioned antibiotics and incubated overnight at $28^{\circ} \mathrm{C}$. The cells were harvested by centrifugating for 20 minutes at $3000 \mathrm{rpm}$. Every pellet was resuspend in $20 \mathrm{ml}$ MES1X + acetosyringone (stock $200 \mathrm{ml}: 20 \mathrm{ml} \mathrm{MES10X}+2 \mathrm{ml} \mathrm{MgCl} 2$ $1 \mathrm{M}+180 \mathrm{Ml}$ water $+200 \mu \mathrm{l}$ acetosyringone 100 $\mathrm{mM}$ ) and then incubated 1.5-2 hour at room temperature. Bacterial suspension was prepared with an O.D.600 of (0.2-0.8) for each bacterial culture. Final concentration of 0.05 of each bacterial suspension was calculated and prepared. The cultures containing the pTRV1 and the pTRV2 vector (or the pTRV2 containing the gene of interest) were mixed in a 1 to $1 \mathrm{~V} / \mathrm{V}$. Also the same was done with pTRV2-PDS control. A $1 \mathrm{ml}$ needless syringe was used to infiltrate the bacterial suspension into both cotyledons of the seedlings. Infiltrated seedlings were kept under greenhouse conditions.

\section{Transformation of bacterial cells}

For transformation of bacterial cells $40 \mu \mathrm{l}$ aliquot of competent cells was thawed on ice, to which was added $1 \mu \mathrm{l}$ of the plasmid carrying the construct of interest. The strain of $E$. coli TOP10 was transformed following the chemical transformation protocol provided by the manufacturer (Invitrogen ${ }^{\circledR}$ ). In the case of the E. coli (strain DH10B), A. tumefaciens (strain C58) and $A$. tumefaciens (strain LBA4404) transformation was performed by electroporation. In all cases the transformed bacterial cells were resuspended in $800 \mu$ of LB medium without antibiotics, and incubated under constant stirring for $1 \mathrm{hr}$., at $37^{\circ} \mathrm{C}$ for E.coli and $2 \mathrm{hr}$., at $28^{\circ} \mathrm{C}$ for A. tumefaciens. After incubation without selection pressure, bacterial cells were plated on LB medium supplemented with selective pressure to select transformed cells.

\section{Plant transformation}

To generate 35S: SIMYB transgenic plants, forward 5'-ATGGATAAAATATGCAACTCT CAAG-3' and reverse 5'-ATCTCCATTAAGCA ATTGCA-3' primers were used to amplify the complete cDNA sequence of SIMYB gene. This sequence was then cloned into pK2GW7 binary vector in sense orientation under the transcriptional control of the cauliflower mosaic virus $35 \mathrm{~S}$ promoter and the $\mathrm{T} 35 \mathrm{~S}$ terminator. On the other hand the same was done to generate 
RNAi-SIMYB transgenic plants by using forward 5'- GAACGGATAACGAGATAAAA - $3^{\prime}$ and reverse 5'- ATCTCCATTAAGCAATTGCA -3' primers to amplify $290 \mathrm{bp}$ from the $3^{\prime}$ end of SIMYB cDNA as a specific region to this gene. This sequence was then cloned into pK7GWIWG2 binary vector in sense and antisense orientation under the transcriptional control of the cauliflower mosaic virus $35 \mathrm{~S}$ promoter and the T35S terminator (Fig. 1). Transgenic plants were generated by Agrobacterium tumefaciens-mediated transformation according to Ellul et al. (2003), and transformed lines were first selected on kanamycin (100 mgl1) and then analyzed by PCR, the presence of kanamycine resistance gene by using 5'GACAAGCCGTTTTACG TTTG-3' and reverse 5'-GATACTTTCTCGGC AGGAG-3' primers as specific primers to the gene of kanamycin resistance and the number of T-DNA insertions according to the segregation ratio of dominant kanamycin resistance gene.

\section{Evaluation of ploidy level}

The ploidy level of obtained transgenic plants was measured by flow cytometric quantification of nuclear DNA content of cells using young leaves of acclimated transgenic plants according to Smulders et al., 1994. The tissue was finely minced in a petri dish on which was added $200 \mu \mathrm{l}$ of nucleus extraction buffer (Partec). The resulting liquid was passed through a nylon mesh of 50 microns and $800 \mu \mathrm{l}$ of a dye solution containing $1 \mathrm{mg} / \mathrm{l}$ of fluorochrome DAPI (4,6-diamino-2-phenyl indole) (DAPI staining solution, Partec) were added, DNA from isolated nuclei was measured using a flow cytometer Partec PAS-II ploidy Analyser. The result showed in a graph represented the data of nuclear DNA content (on the horizontal axis) and the counted number of nuclei of each type (in the vertical axis). The peak corresponding to a DNA content equal to $2 \mathrm{n}$ (diploid) was used for calibration.

\section{Cytolocalization analysis}

Agroinfiltration experiments were performed on $N$. benthamiana grown in the greenhouse. Plants were grown for 6-8 weeks before infiltration. Binary plasmids (pEarleyGate 101 and pEarleyGate 104) were recombined with complete cDNA of SIMYB gene to be under the control of $35 \mathrm{~S}$ promoter and fused to YFP gene. Binary plasmids were transformed into Agrobacterium tumefaciens strain C58 and incubated for 2 days on LB medium supplemented with kanamycin, rifampicin and gentamicin $50 \mathrm{mg} / 1$ to select for transformed Agrobacterium cells. For agroinfiltration the transformed Agrobacterium tumefaciens strain C58 were incubated for 2 days in LB medium supplemented with the same antibiotics. The optical density at $600 \mathrm{~nm}$ was measured and suspensions were made for co-infiltrations with a final OD600 of 0.3 in $2 \mathrm{ml}$ of infiltration solution $\left(200 \mu \mathrm{l}\right.$ MES, $20 \mu \mathrm{l} \mathrm{MgCl}_{2}, 4 \mu \mathrm{l}$ acetosyringone, $1776 \mu$ l distilled water) for each plant. Agroinfiltration of young leaves of $N$. benthamiana was done as described by Feller $e t$ al. (2006). Two to three days later, infiltrated leaf areas were excised and localization of green fluorescent protein (YFP) was determined by confocal laser scanning microscopy.

\section{Data analysis}

Statistical analyses were performed using Microsoft Excel. If two observations are described as different this means that their difference was determined to be statistically significant $(\mathrm{P}<0.05)$ by the performance of Student's t-tests.

(A)

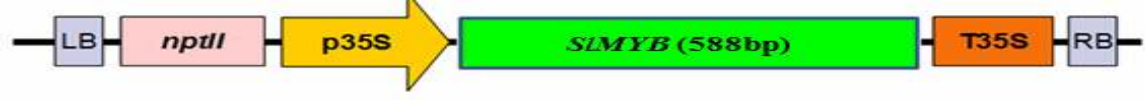

(B)

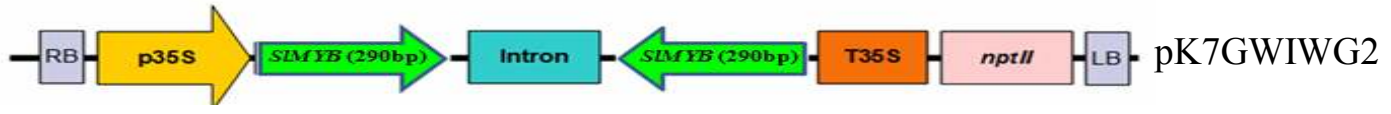

Fig. 1. Schematic representation of the constructions used for transformation of tomato. (A) The construction of overexpression (35S: SIMYB). (B) Construction of silencing (RNAiSIMYB) 


\section{RESULTS AND DISCUSSION}

\section{In Silico Analysis of SIMYB Gene}

The transcript identified in the genomic analysis corresponds with the unigen SGNU576253 and was renamed as SIMYB (Solanum lycopersicum MYB). The genomic sequence of SIMYB gene was analysed in silico and includes the 588 bp coding sequence in three exons (133 bp, $130 \mathrm{bp}, 325 \mathrm{bp}$ respectively from $5^{\prime}$ to $3^{\prime}$ ) flanked by a $5^{\prime}$ untranslated region ( $5^{\prime}$ UTR) of $96 \mathrm{bp}$ and a $3^{\prime}$ untranslated region (3' UTR) of $223 \mathrm{bp}$ and contains two introns (292 bp and $2431 \mathrm{bp}$, respectively from $5^{\prime}$ to $3^{\prime}$ ) (Fig. 2). The deduced protein sequence produces a typical R2R3 MYB protein of 195 amino acids with a calculated molecular weight of 22.42 $\mathrm{kDa}$.

Bioinformatics analysis of the protein sequence identified the presence of two domains of R2R3 MYB protein and each domain contain a helix-turn-helix (HTH) motif (Fig. 3). Type R2R3 MYB proteins are transcription factors which play an important role in eukaryotic cells, as they regulate different pathways of transduction signal and control processes such as development and programmed cell death. This domain allows the interaction or binding to DNA, RNA or other proteins.

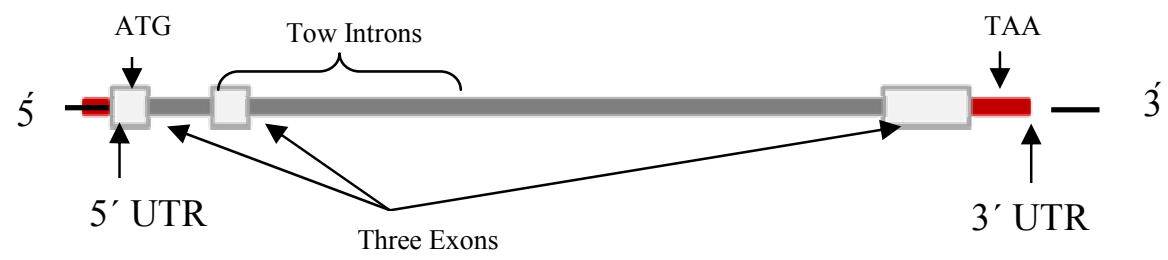

Fig.2. The genomic SIMYB gene structure

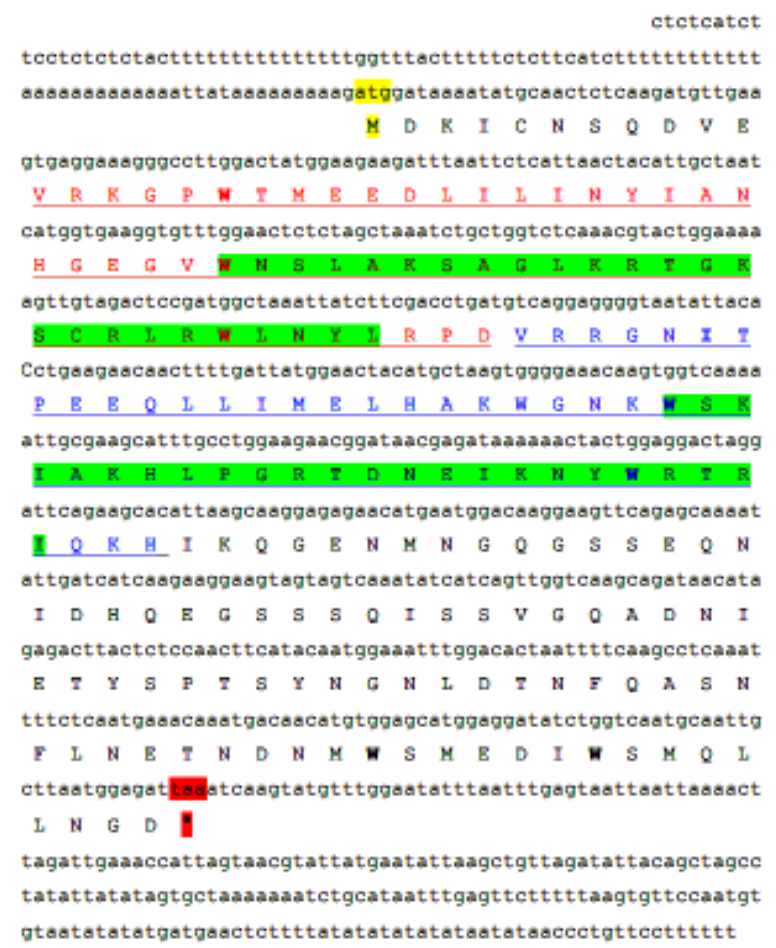

Fig. 3. (A) Nucleotide and protein sequence of SIMYB. Start codon is indicated in yellow while stop codon is indicated in red. R2MYB domain (53aa) is indicated in red and the blue indicates the R3MYB domain (51aa). Green color indicates the DNA binding domain (helix-turn-helix (HTH) motifs). Tryptophan and isoleucine residues are highlighted in bold

Note: aa (amino acid) 
MYB proteins are characterized by a highly conserved DNA-binding domain (the MYB domain). This domain generally consists of up to four imperfect amino acid sequence repeats (R) of about 52 amino acids, each forming three $\alpha$-helices. The second and third helices of each repeat build a helix-turn-helix (HTH) structure with three regularly spaced tryptophan and isoleucine (or hydrophobic) residues, forming a hydrophobic core in the 3D HTH structure (Ogata et al.,1996). The third helix of each repeat is the "recognition helix" that makes direct contact with DNA and intercalates in the major groove (Jia et al., 2004). During DNA contact, two MYB repeats are closely packed in the major groove, so that the two recognition helices bind cooperatively to the specific DNA sequence motif.

Alignment was performed using homologous proteins ClustalW0 program. A highly conserved region corresponding to the R2 and R3 MYB domains. The presence of the conserved tryptophan and isoleucine residues within every MYB domain have been also identified (Fig. 4).

The alignment of the complete sequences of the 15 MYB proteins of different plant species that are similar to SIMYB, a dendrogram was generated using Uniprot database (http://www. uniprot.org). Fig. 5 shows the degree of similarity between the deduced protein and the other plant MYB proteins of different plant species. The SIMYB protein has a degree of similarity with proteins from the same family (Solanaceae) ranged between $83 \%$ - 86\% while the degree of similarity with homologous proteins from other families ranged between $70 \%-78 \%$.

Although the MYB gene superfamily comprises one of the largest families of transcription factors known to date, the functional roles of most plant MYB genes are largely unknown. Interestingly, plant R2R3 MYB genes have a highly conserved N-terminal MYB domains, but have dramatically divergent C-terminal regions (Fig. 4). Recently, conserved motifs within the C-terminal regions of paralogous and orthologous MYB genes have been identified (Stracke et al., 2001). These conserved motifs may reflect constraints upon the functions of related Myb proteins.

\section{Cytolocalization of SIMYB Gene}

In eukaryotes, transcription factors are transcribed in the nucleus but are then translated in the cytoplasm of the cell. Many proteins that are active in the nucleus contain nuclear localization signals that direct them to the nucleus. But, for many transcription factors, this is a key point in their regulation (Whiteside and Goodbourn, 1993). To examine the subcellular localization of SIMYB, the constructions p35S:: SIMYB-YFP and p35S::YFP-SIMYB were generated by using pEarleyGate 101(C-YFPHA) and pEarleyGate 104 (N-YFP) as a destination vectors. Agroinfiltration into $N$. benthamiana leaves shows that YFP fluorescence was detected in both cases in the cytoplasm and the nucleus which indicate that the gene of interest works as transcription factor (Fig. 6).

\section{Analysis of SIMYB Gene Expression Pattern}

\section{qRT-PCR analysis}

SIMYB gene expression was assessed at different developmental stages and plant organs by quantitative real-time PCR (qRT-PCR). To determine the expression of SLMYB gene, two oligonucleotides were designed to amplify a fragment of $52 \mathrm{bp}$ at the 3 'end of the gene, which is intended to detect only the candidate gene expression; because this region is specific to SIMYB as MYB genes are divergent in the 3' end (Fig. 4). The cDNA was reverse transcribed from RNA extracted from 7 days old seedling (from apical meristem and root), young leaves from adult plants and flowers in various stages of development (flowers 6, 4, 2 days before anthesis, flowers at anthesis and flowers 2, 4 days after anthesis).

It has been showen a very low levels of transcript in vegetative tissues (apical meristems, leaves and roots) compared to the high level observed in reproductive tissues. During the development of the flower, the highest level of expression was detected in flowers at anthesis (Fig. 7A). This expression pattern suggests that this gene is required during flower development.

In order to confirm the role of SIMYB gene in flower development the expression of the gene was analyzed in the different flower organs at the anthesis stage; it was observed that the gene is expressed in all the organs and the highest level of gene expression is localized in stamens (Fig. 7B). 
CLUSTAL O (1.1.0) multiple sequence alignment

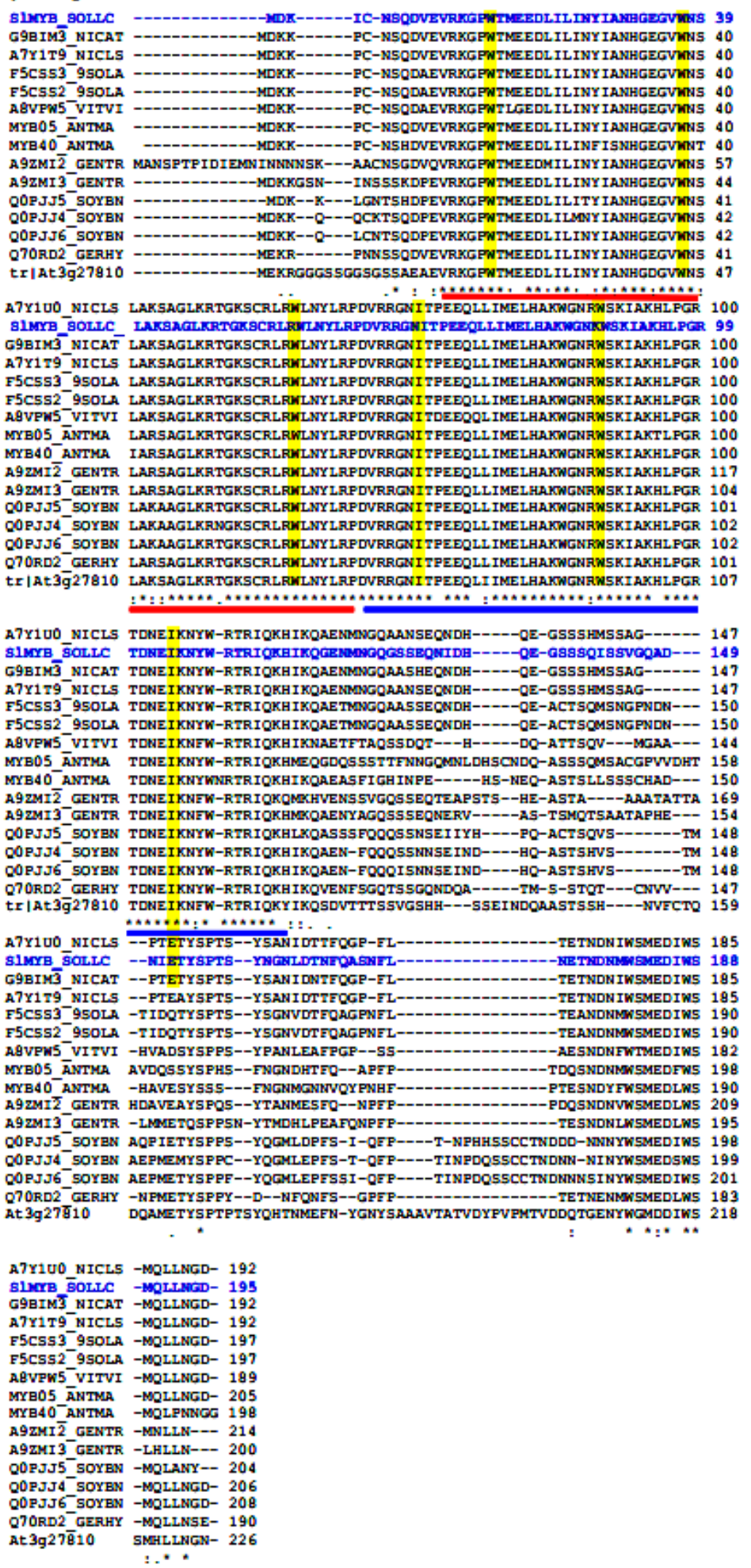

Fig. 4. Alignment of the deduced R2R3 MYB protein type from Solanum lycopersicum with proteins from other species of plants. Protein alignment was generated using ClustalWo. The red line indicates the R2 MYB domain (55aa) and the blue line indicates the R3 MYB (51aa). Tryptophan and isoleucine residues are indicated in red and blue boxes in both $R 2$ and $\mathrm{R3}$ domain, respectively 


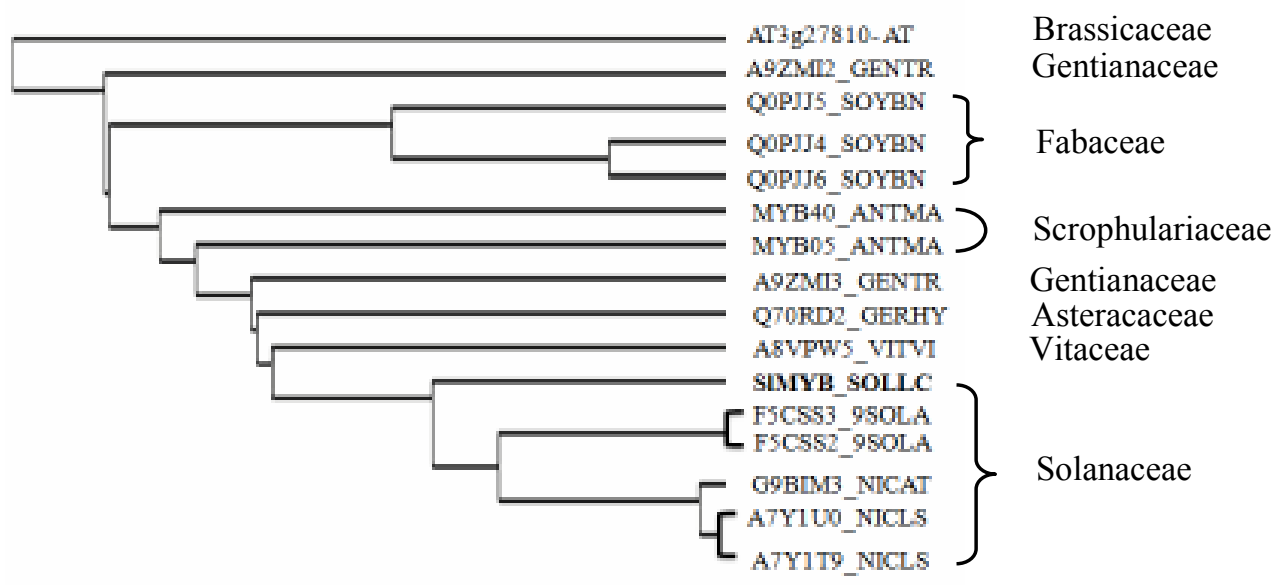

Fig. 5. Phylogenetic tree displaying the similarity of SIMYB (in bold) to other R2R3 MYB proteins. The tree was constructed using Uniprot database

(A)
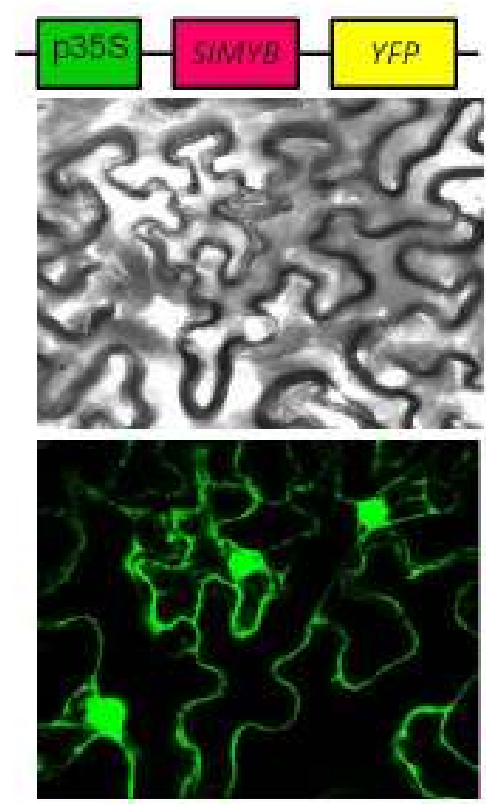

(B)
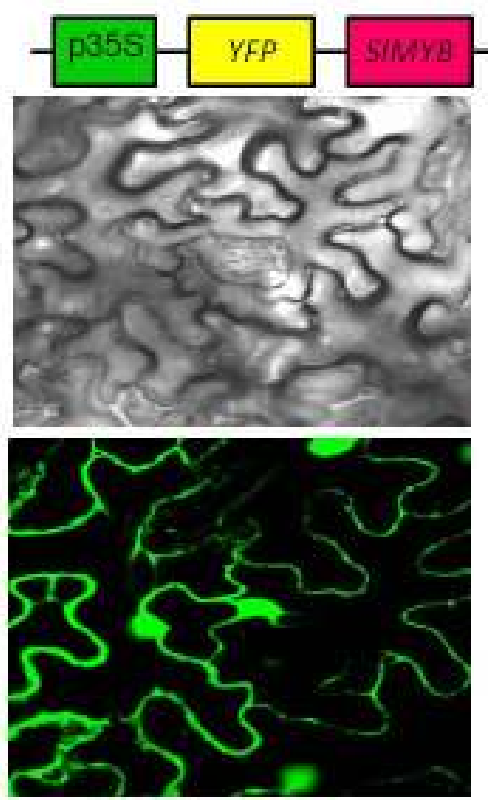

\section{Fig. 6. Cytolocalization of SIMYB}

A. Nicotiana benthamiana leaf cells agroinfiltrated with SIMYB-YFP in pEarleyGate 101 (C-YFP-HA) vectors

B. Nicotiana benthamiana leaf cells agroinfiltrated with SIMYB-YFP in pEarleyGate 104 (N-YFP) vectors. Both of them show green fluorescence in the nucleus and the cytoplasm. 


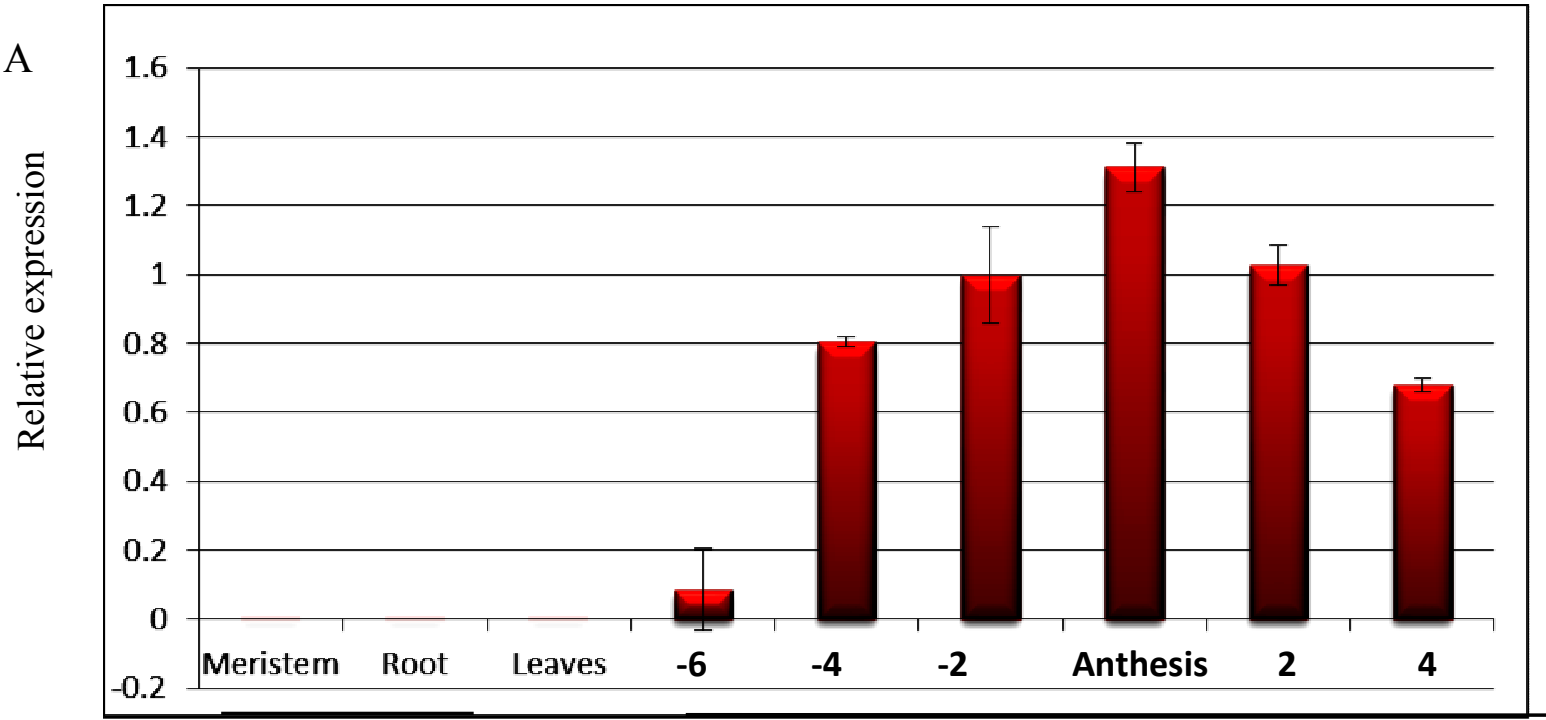

Seedling stage Flowering

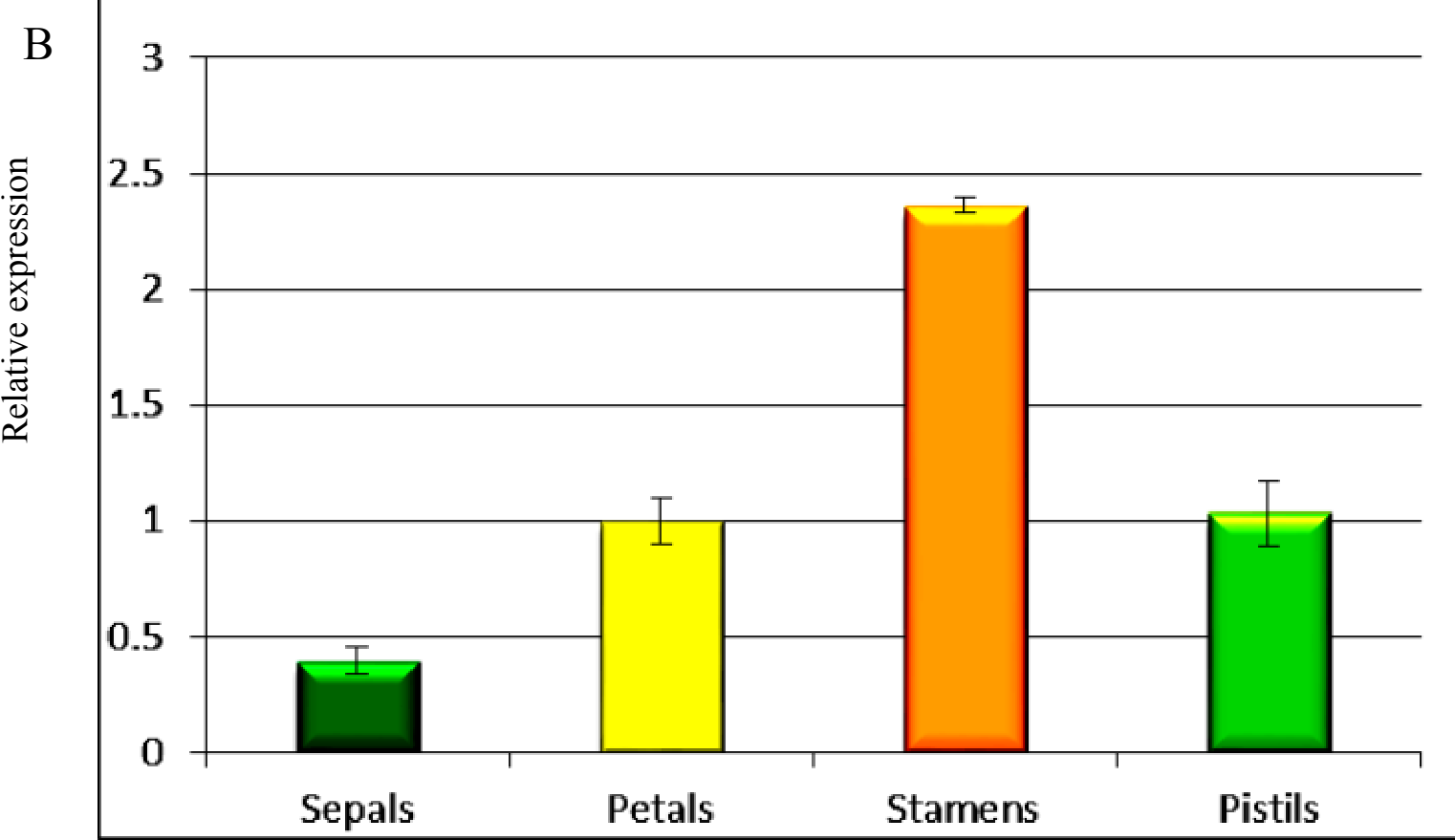

Fig. 7. Relative expression of SIMYB gene in wild type tomato cv. Micro-Tom. A. Transcript level in the apical meristem and root of 7-day-old seedlings, adult plant leaves, flowers of six, four and two days before anthesis, flowers at anthesis and flowers two and four days after anthesis. Expression levels were relating to the expression in the flowers two days before anthesis (-2). B. Expression level in flower organs in flowers at anthesis. The valus are relative to the expression level in petals. The level of gene expression was quantified by $q R T-P C R$ using specific primers and the SIACT8 endogenous gene as a normalizer 
The homologous gene from Arabidopsis (At3g27810) has similar expression in different plant parts and in flower organs. This gene encodes a member of the R2R3-MYB transcription factor gene family, induced by jasmonate and involved in jasmonate response during stamen development

\section{In situ hybridization analysis}

To determine the expression of SIMYB gene in flower tissues, in situ hybridization was performed using an RNA probe labeled with dioxygenin. The probe was synthesized from a fragment of $290 \mathrm{bp}$ corresponding to the $3^{\prime}$ region of the gene, cloned in antisense direction against T7 promoter. The evaluation was performed in reproductive tissues, and sections were obtained from floral meristem, flowers 6 days befor anthesis, flowers 4 days befor anthesis, flowers 2 days before anthesis and flowers at anthesis. In situ hybridization showed that the expression of SIMYB gene appeared in all tested stages except floral meristem. Results showed that SIMYB transcript is located in the stamens and carpels (Fig. 8). In particular signal within the ovary is located on ovules. This suggests that the gene may participate in ovules development and located in stamen cells which suggest that the gene may be involved in stamens development.

Gain of function (overexpression) of SIMYB gene increases the number of seeds in tomato fruits

For the overexpression of the complete cDNA of SIMYB gene (588 bp) was amplified by PCR by designing a pair of specific primers that amplify the sequence from ATG to the stop codon. Ovaries and stamens cDNA libraries of tomato (cv. Micro-Tom) were used as a template in PCR. The complete cDNA was inserted by recombination reaction into the destination vector pK2GW7 to be under the control of constitutive $35 \mathrm{~S}$ promoter (Fig. 1 materials and methods) generating the construction $35 \mathrm{~S}$ : SIMYB.

This construct was used to genetically transform tomato plants of Micro-Tom cultivar. A. tumefaciens LBA4404 strain was used for transformation and cotyledons explants were used as plant material. Regenerated explants without inoculation with $A$. tumefaciens were obtained to be used as a control in subsequent analysis. It was obtained 2 primary transgenic shoots for the construction of overexpression 35S:: SIMYB (Fig. 9). The transgenic plants were analyzed by flow cytometry to assess ploidy level and they proved to be diploid $(2 n)$. The presence of a 583 bp fragment corresponding to the nptII gene was detected in the plants indicating that the resulted plants have the overexpression construction. Three generations were cultivated to obtain the homozygous plants. Relative expression of SIMYB gene was measured in flowers at anthesis in T3 homozygous lines showed that the gene of interest is overexpressed (Fig. 10A). The phenotype of $\mathrm{T} 3$ plants growing under the greenhouse conditions was analyzed. These plants showed no differences in the vegetative development. But the fruits of these plants had a large number of seeds (Fig. 10D). The difference in the number of seeds between the T3 plants, control plants was statistically significant (Fig. 10B).

Numerous R2R3-MYB proteins have been characterized by genetic approaches and found to be involved in the control of plant-specific processes in Arabidopsis including regulation of cell fate and identity (Jakoby, 2008; Li, 2009), regulation of developmental processes such as anther development and/or functionality (Millar and Gubler, 2005; Zhang, 2007; Cheng, 2009; Mandaokar and Browse, 2009) and controlling male germ cell division and differentiation (Brownfield et al., 2009).

\section{Loss of Function (Silencing) of SIMYB Gene Lead to the Reduction of Fruit Set and Production of Fruits with Low Number of Seeds}

\section{Stable silencing}

To generate the construct to obtain stable silencing pair of primers were designed (materials and methods) that amplify a fragment of $290 \mathrm{bp}$ corresponding to the 3'region of the coding sequence of SIMYB gene. This fragment was chosen as a gene specific fragment. The fragment was recombined in the silencing vector pK7GWIWG2 containing the $35 \mathrm{~S}$ promoter 

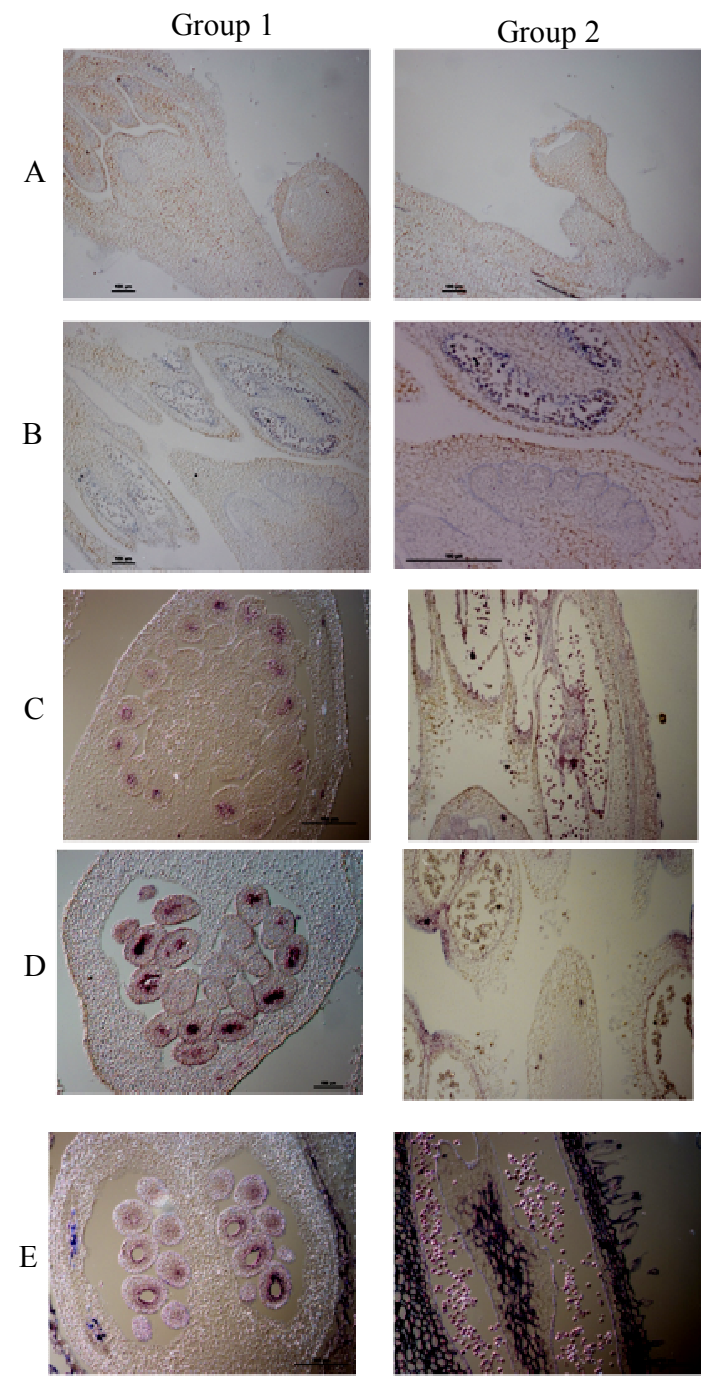

Ovules

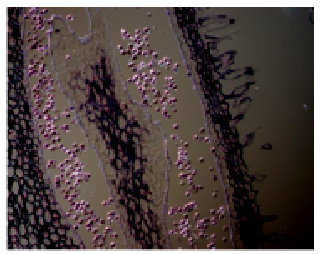

Stamens
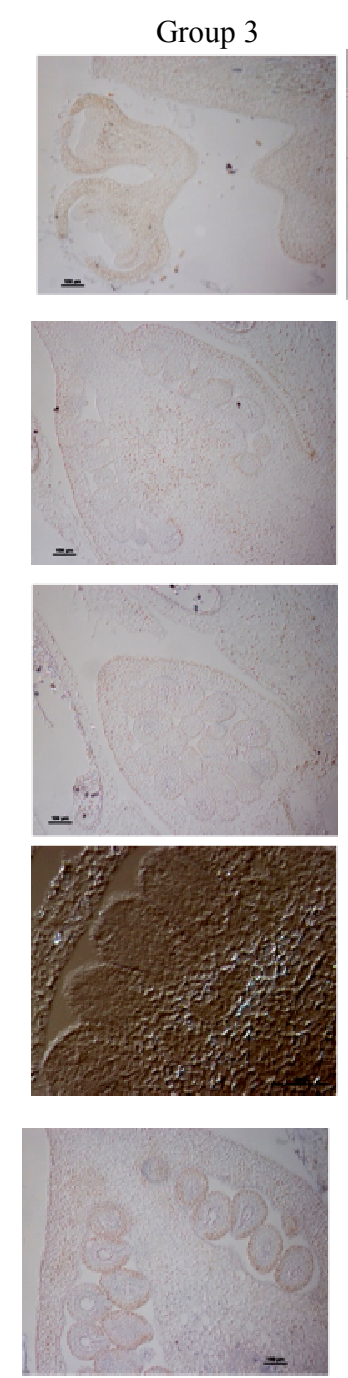

Ovules

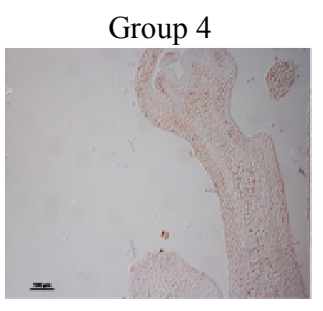

Floral meristem

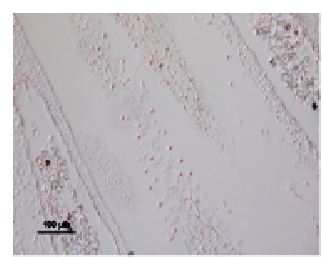

6 days befor anthesis

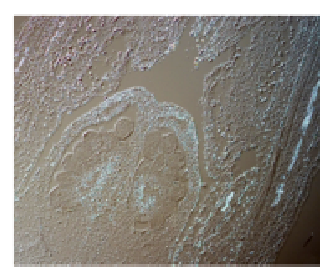

4 days befor anthesis

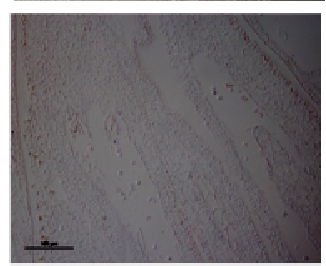

2 days befor anthesis

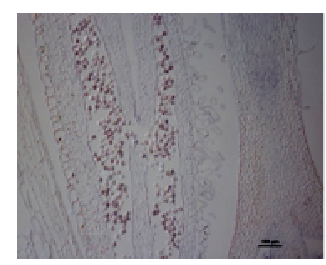

Stamens

Anthesis

Fig. 8. Transcript location of SIMYB gene in tomato flowers cv. Micro-Tom by in situ hybridization. (A) Expression of SIMYB gene in floral meristem. (B) Expression of SIMYB gene in flowers 6 days befor anthesis. (C) Expression of SIMYB gene in flowers 4 days befor anthesis. (D) Expression of SIMYB gene in flowers 2 days befor anthesis. (E) Expression of SIMYB gene in flowers at anthesis. Groups 1, 2 indicate the expression of SIMYB gene in ovules and stamens, respectively; Groups 3, 4 indicate the control in ovules and stamens, respectively. Bars in all photos are $100 \mu \mathrm{m}$. 


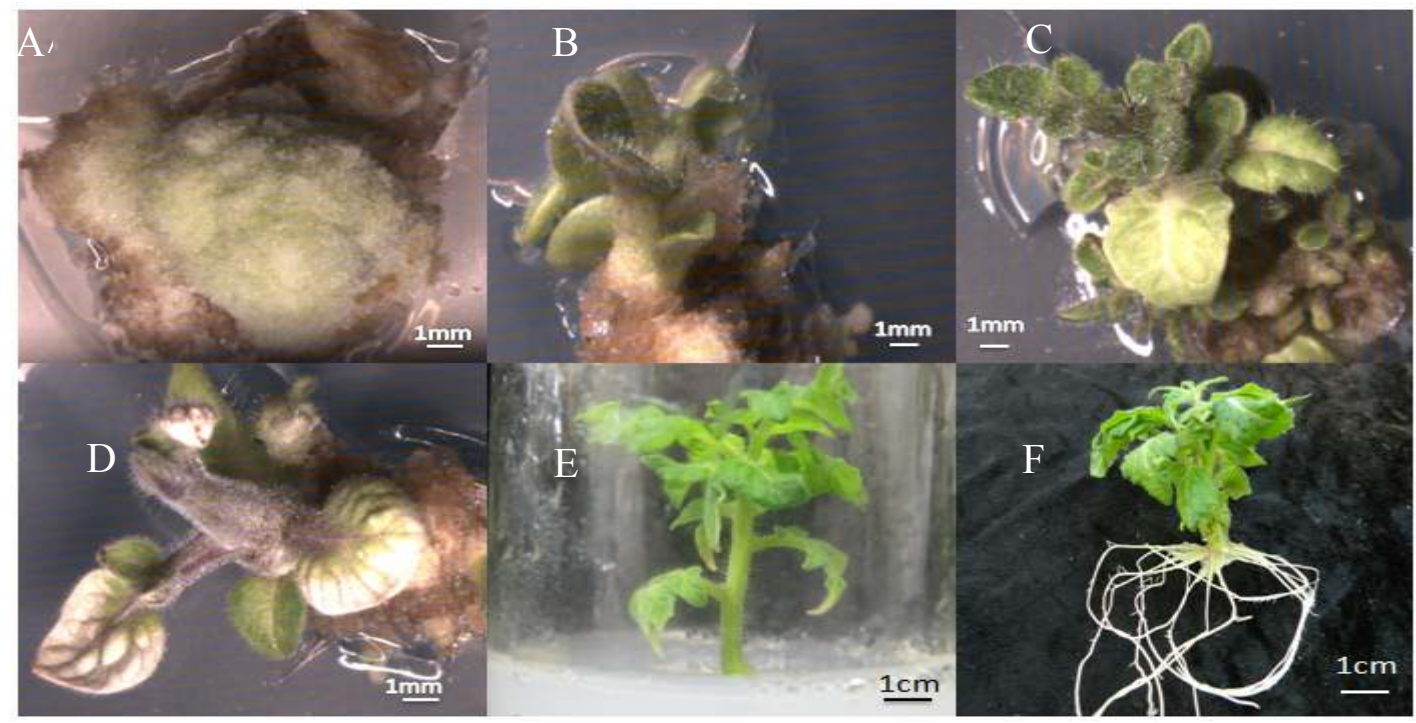

Fig. 9. 35S::SIMYB T1plants, organogenic response of cotyledon explants inoculated with $A$. tumefaciens. (A) Organogenic callus after 2 weeks of culture. (B-D) Organogenic callus with buds begin to form the first adventitious shoots. (D) Adventitious bud after 6 weeks of culture. E. Individual plants on rooting medium. (F) Transgenic rooted plant, ready for acclimatization in the greenhouse, after 12 weeks of culture.
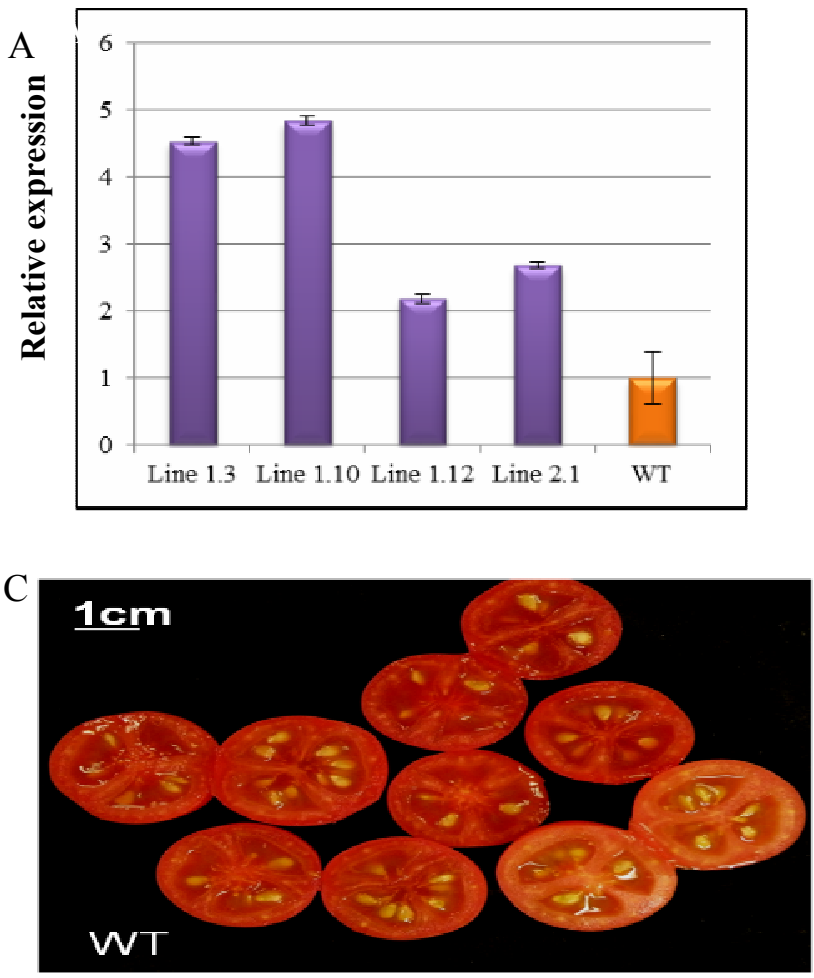
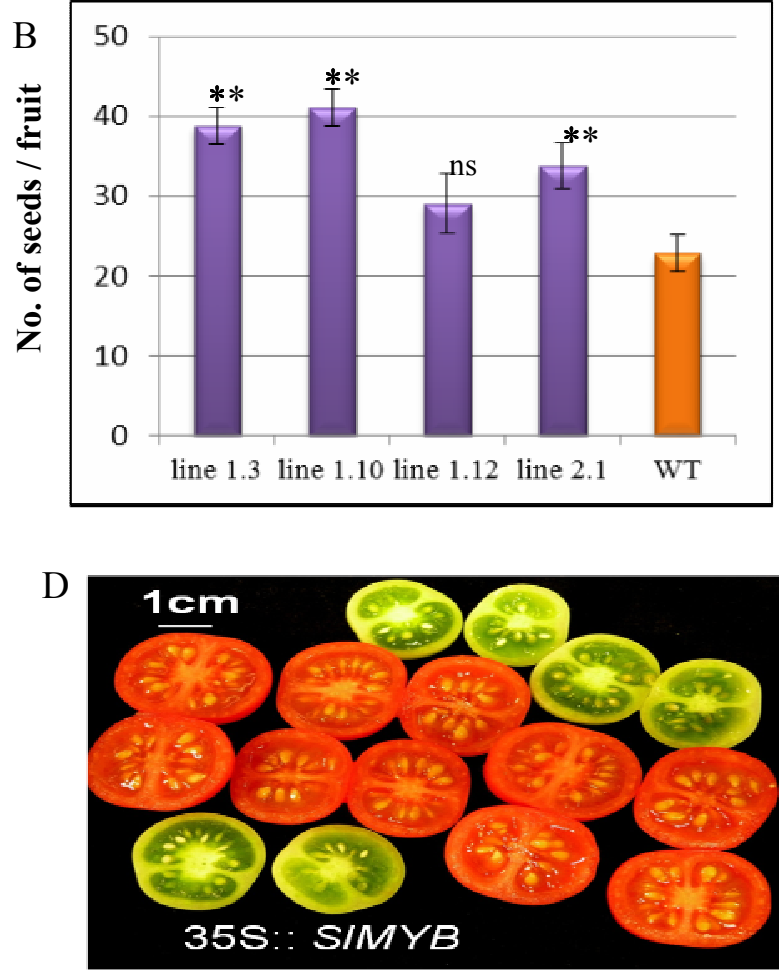

Fig. 10.A. Relative Expression of SIMYB gene in flowers at anthesis of T3 lines and wild type tomato cv. Micro-Tom. The values are relative to the expression level in WT. The level of gene expression was quantified by qRT-PCR using specific primers and the SIACT8 endogenous gene as a normalizer. B. Number of seeds of T3 homozygous plants and wildtype. C. Fruits morphology of nontransgenic plants (WT). D. Fruits morphology of T3 transgenic lines of 35S::SIMYB overexpression.

Note: In figure B the presented data is the Mean values of 20 fruits (4 fruits x 5 plants/line and standard errors, 
after two inverted Gateway cloning sites separated by an intron. Thus, SIMYB cDNA fragment was cloned into the vector pK7GWIWG2 twice, in direct and inverted form, separated by intron (Fig. 1 materials and methods) generating the construction RNAiSIMYB which used to genetically transform tomato plants Micro-Tom cultivar (the same as mentioned in the gain of function section), 4 independent plants were obtained for this construction. The transgenic plants were analyzed by flow cytometry to assess ploidy level, only one of them was diploid (2n). Relative expression of SIMYB gene was measured in flowers at anthesis in $\mathrm{T} 1$ plant and showed that the gene of interest is completely scilenced (Fig. 11F). T1 plant showed no differences in the vegetative development. The stable silencing of SLMYB gene leads to the reduction of pollen grain fertility as found in pollen grain germination experiment $(2.91 \%$ in RNAi pollen, $60.77 \%$ in control pollen) (Fig. 11 $\mathrm{D}, \mathrm{E}$ ), consequently the prevention of fruit set and fruit development (Fig. 11A). To check the effect of SLMYB on the development of flower ovary, RNAi plants were used as female and wild type plants were used as male plants in a hybridization experiment, the resulted fruits were seedless fruits (Fig. $11 \mathrm{G}, \mathrm{H}$ ) indicating that the silencing of the gene of interest leads to the undevelopment of the ovules which insure that the SLMYB gene is involved in fruit development and seed formation.

\section{Transient silencing}

In the case of the transient silencing, the method of virus induced gene silencing (VIGS) was used. The PTRV2-GW was used as a destination vector where a 290 bp fragment corresponding to the $3^{\prime}$ region of the coding sequence of SIMYB gene was recombined. A mixture of Agrobacterium cultures containing (pTRV1 + pTRV2 - SIMYB) were infiltrated onto the cotyledons and lower leaves of 3-week- old tomato cv. Micro-Tom plants. As a positive control the expression of the endogenous phytoene desaturase gene (PDS) in Micro-Tom tomato was suppressed. A mixture of Agrobacterium cultures containing pTRV2, carrying tomato PDS (pTRV2-PDS) and pTRV1 were infiltrated onto the cotyledons and lower leaves of 3-week-old tomato plants. These plants developed a photo-bleached phenotype in the upper leaves 10 days post-agro-infiltration Fig. $12 \mathrm{~A}$ shows the agroinfiltration of pTRV-PDS resulted in the PDS silencing phenotype in five out of five tomato plants (100\% efficiency), while the agroinfiltration of pTRV-SIMYB resulted in the SIMYB silencing phenotype in 7 out of 10 tomato plants ( $70 \%$ efficiency). The relative expression of SIMYB was measured in flowers at anthesis by using qPCR. The analysis showed low levels of expression in silenced plants compared to a normal level in control plants (Fig. $12 \mathrm{G}$ ). The phenotype resulting from SIMYB silencing was the reduction of fruit set percentage (13.4\%:35.1\% in silenced plants and $61.25 \%$ in control plants) (Fig. 12E, F) and the production of low number of fruits with very low number of seeds compared to the control plants (Fig. 12 D, H) compared to a normal number of seeds in negative control plants.

It was demonstrated in several studies that VIGS via the pTRV system is a fast and highly effective tool for gene downregulation in tomato (Liu et al., 2002; Burch-Smith et al., 2004; Dong et al., 2007). The PDS gene was chosen as a positive control to test the ability of the system to induce gene silencing because it allows the detection of symptoms in different plant organs such as stems, leaves, pedicels, sepals, petals and also in anthers (Hileman et al., 2005).

The $290 \mathrm{bp}$ fragment that was used for silencing seems to be specific to the gene of interest suggesting that the obtained phenotypes by silencing is specific to the SIMYB. 
A
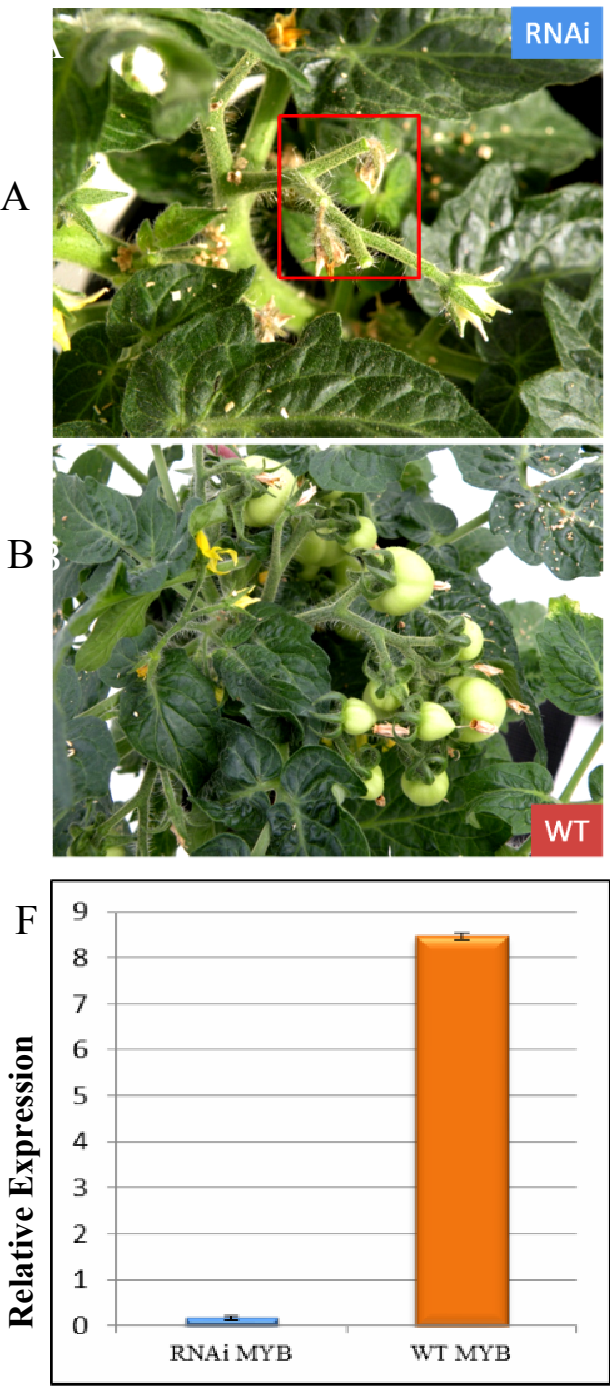
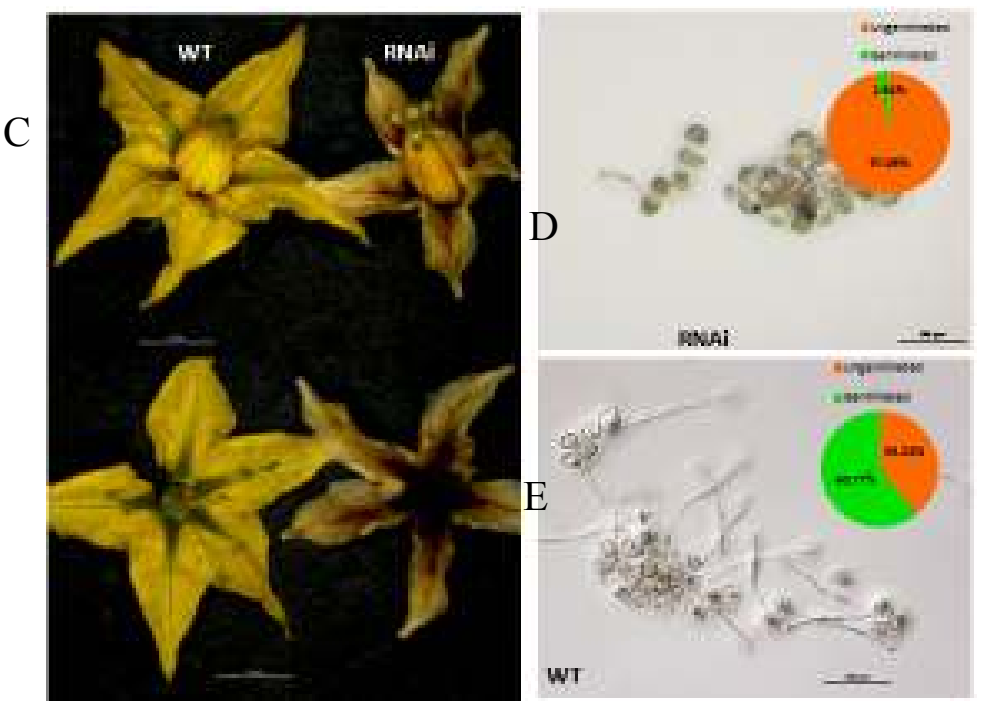

G
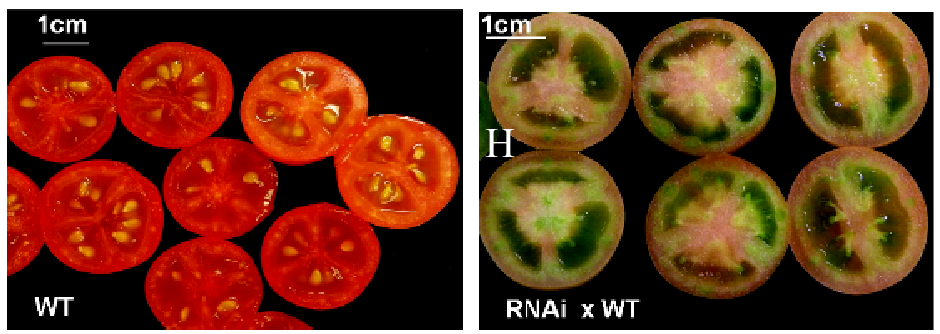

Fig. 11. Morphological characterization of SIMYB gene silencing in tomato plants by RNAi method. (A) Morphology of RNAi plant showing the death of flowers as a result of SLMYB gene scilencing. (B) Morphlogy of control plant with normal fruit set. (C) Morphology of flowers in RNAi and control plants. (D) Percentage of pollen grains germination RNAi plant. (E) Percentage of pollen grains germination RNAi plant. (F) Relative Expression of SIMYB gene in flowers at anthesis of T1 RNAi line and wild type tomato cv. Micro-Tom. (G) Fruits of control plant with normal seeds. (H) Fruits resulted from hybridization of RNAi plants with control plant showing undeveloped ovules 

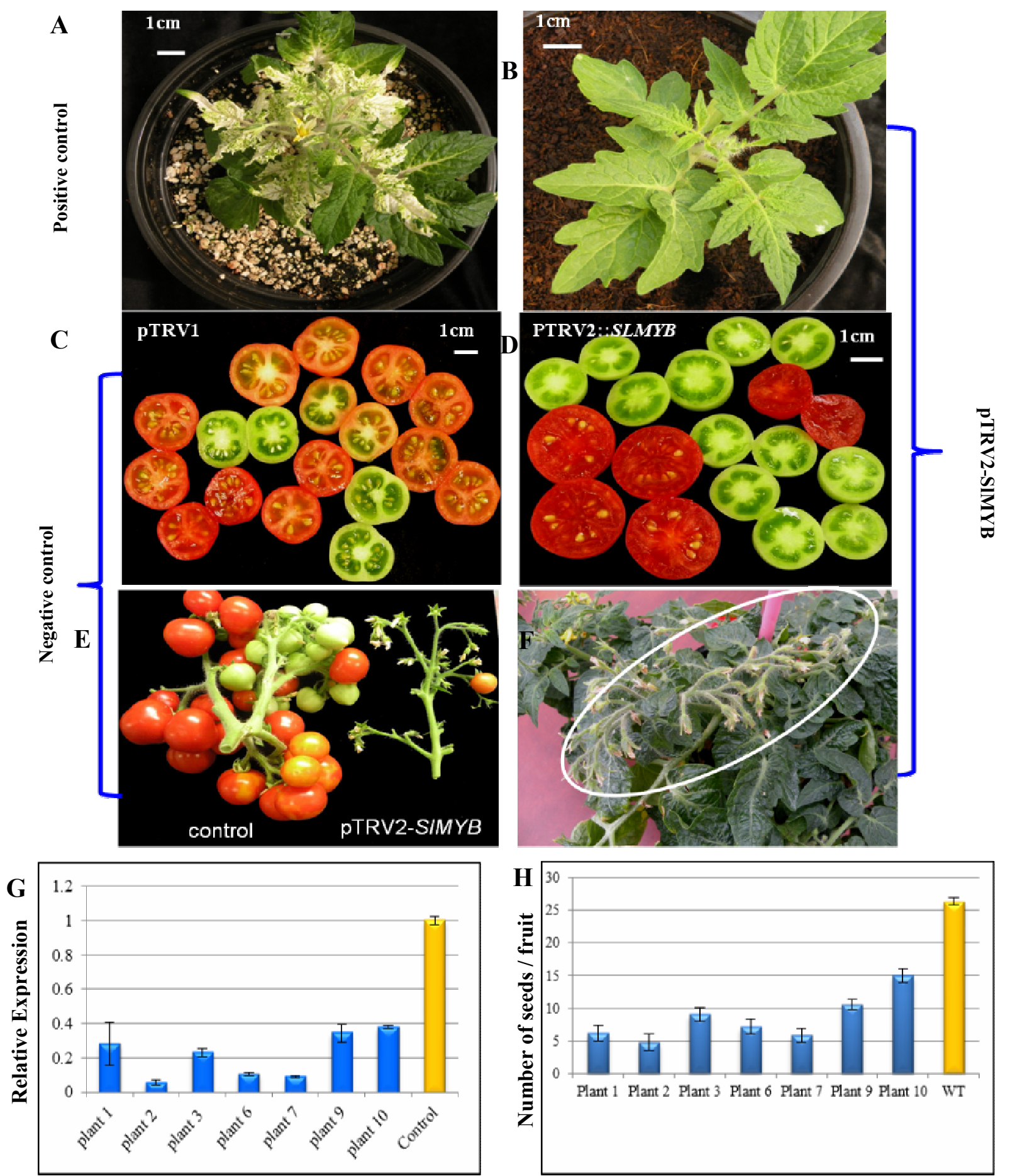

Fig. 12. Morphological characterization of SIMYB gene silencing in tomato plants by VIGS method. (A) Tomato plant cv. Micro-Tom 10 days post-agro-infiltration with PDS gene (control). (B) Infiltrated plant using pTRV1 and pTRV2-SIMYB gene. (C) Fruits of negative control plants with normal number of seeds (D) Fruits of silenced plants fruits with very low number of seeds. $(E, F)$ The phenotype resulting from SIMYB silencing indicating the percentage of fruit set reduction. (G) Relative Expression of SIMYB gene in flowers at anthesis of VIGS plants and wild type tomato cv. Micro-Tom. (H)Number of seeds in VIGS plants and wild type tomato cv. Micro-Tom 


\section{REFERENCES}

Achard, P., W.H. Vriezen, D. van der Straeten, and N.P. Harberd (2003). Ethylene regulates Arabidopsis development via the modulation of DELLA protein growth repressor function. Plant Cell, 15 : 2816-2825.

Alba, R., P. Payton, Z. Fei, R. McQuinn, P. Debbie, G. Martin, S.D. Tanksley and J. Giovannoni (2005). Transcriptome and selected metabolite analyses reveal multiple points of ethylene control during tomato fruit development. Plant Cell., 17: 2954-2965.

Ambawat, S., P. Sharma, N.R. Yadav and R.C. Yadav (2013). MYB transcription factor genes as regulators for plant responses: an overview. Physiol. Mol. Biol. Plants, 19: 307-321.

Behm-Ansmant, I., J. Rehwinkel , E. Izaurralde (2006). MicroRNAs silence gene expression by repressing protein expression and/or by promoting mRNA decay. ColdSpring Harb. Symp. Quant. Biol., 71: 523-530

Bemer, M., R. Karlova, A.R. Ballester, Y.M. Tikunov, A.G. Bovy, M. Wolters-Arts, B. Rossetto Pde, G.C. Angenent and R.A. de Maagd (2012). The tomato FRUITFULL homologs TDR4/FUL1 and MBP7/FUL2 regulate ethylene-independent aspects of fruit ripening. The Plant Cell., 24: 4437-4451.

Brownfield, L. (2009). A plant germline-specific integrator of sperm specification and cell cycle progression. PLoS Genet., 5:e1000430.

Burch-Smith, T.M., J.C. Anderson, G.B. Martin and S.P. Dinesh-Kumar (2004). Applications and advantages of virus-induced gene silencing for gene function studies in plants. P1. J., 39 : $734-746$.

Cao, D., A.Hussain, H. Cheng and J. Peng (2005). Loss of function of four DELLA genes leads to light- and gibberellinindependent seed germination in Arabidopsis. Planta, 223 105-113.

Cheng, H. (2009). Gibberellin acts through jasmonate to control the expression of MYB21, MYB24, and MYB57 to promote stamen filament growth in Arabidopsis. PLoS Genet, 5: e1000440.
Cheng, H., L. Qin, S. Lee, X. Fu, D.E. Richards, D. Cao, D. Luo, N.P. Harberd and J. Peng (2004). Gibberellin regulates Arabidopsis floral development via suppression of DELLA protein function. Dev., 131 : 10551064.

Chung, M.Y., J. Vrebalov, R. Alba, J. Lee, R. McQuinn, J.D. Chung, P. Klein and J. Giovannoni (2010). A tomato (Solanum lycopersicum) APETALA2/ERF gene, SIAP2a, is a negative regulator of fruit ripening. Plant J., 64:936-947.

Dill, A. and T.P. Sun (2001). Synergistic derepression of gibberellin signaling by removing RGA and GAI function in Arabidopsis thaliana. Genet., 159 777-785.

Dong T., Z. Hu, L. Deng, Y. Wang, M. Zhu, J. Zhang and G. Chen (2013). A tomato MADS-box transcription factor, SLMADS1, acts as a negative regulator of fruit ripening. Plant Physiol., 163: 1026-1036.

Dong, Y., TM. Burch-Smith, Y.L. Liu, P. Mamillapalli and S.P. Dinesh-Kumar (2007). A ligation-independent cloning TRV vector for high-throughput virus-induced gene silencing identifies roles for NbMADS4-1 and -2 in floral development. Pl. Physiol., 145:1161-70.

Ellul, P., B. Garcia-Sogo, B. Pineda, G. Ríos, LA. Roig and V. Moreno (2003). The ploidy level of transgenic plants Agrobacteriummediated transformation of tomato cotyledons (Lycopersicon esculentum. L. Mill.) is genotype and procedure dependent. TAG Theoretical and Appl. Genet., 106: 231-238.

Feller, A., J.M. Hernandez and E. Grotewold (2006). An ACT-like domain participates in the dimerization of several plant basic-helixloop-helix transcription factors. J. Biol. Chem., 281 : 28964-28974.

$\mathrm{Fu}, \mathrm{X}$. and N.P. Harberd (2003). Auxin promotes Arabidopsis root growth by modulating gibberellin response. Nat., 421 740-743.

Fujisawa, M., Y. Shima, H. Nakagawa, M. Kitagawa, J. Kimbara, T. Nakano, T. Kasumi and Y. Ito (2014). Transcriptional regulation of fruit ripening by tomato FRUITFULL homologs and associated MADS box proteins. The Plant Cell., 26: 89-101. 
Giovannoni, J.J. (2004). Genetic regulation of fruit development and ripening. Plant Cell (Suppl), 16: S170-S180.

Griffiths, J., K. Murase, I. Rieu, R. Zentella, ZL. Zhang, SJ. Powers, F. Gong, AL. Phillips, P. Hedden, TP. Sun and SG. Thomas (2006). Genetic characterization and functional analysis of the GID1 gibberellin receptors in Arabidopsis. P1. Cell., 18: 3399-3414.

Hileman, L.C., S. Drea, G. de Martino, A. Litt and VF. Irish (2005). Virus-induced gene silencing is an effective tool for assaying gene function in the basal eudicot species Papaver somniferum (opium poppy). Pl. J., 44: 334-341.

Itkin, M., H. Seybold, D. Breitel, I. Rogachev, S. Meir and A. Aharoni (2009). TOMATO AGAGAMOUS-LIKE1 is a component of the fruit ripening regulatory network. Pl. J. 60:1081-1095.

Jakoby, M.J. (2008). Transcriptional profiling of mature Arabidopsis trichomes reveals that NOECK encodes the MIXTAlike transcriptional regulator MYB106. Pl. Physiol., 148 : 1583 1602.

Jia, L., T.C. Michael and T. Jiang (2004). Evolutionary dynamics of the DNA-binding domains in putative R2R3-MYB genes identified from rice subspecies indica and japonica genomes. Pl. Physiol., 134 : 575585.

King, K., T. Moritz and N. Harberd (2001). Gibberellins are not required for normal stem growth in Arabidopsis thaliana in the absence of GAI and RGA. Genet., 159 : $767-$ 776.

Klee, H.J. and J.J. Giovannoni (2011). Genetics and Control of Tomato Fruit Ripening and Quality Attributes. Annual Rev. Genet., 45: 41-59.

Lee, S., H. Cheng, K.E. King, W. Wang, Y. He, A. Hussain, J. Lo, N.P. Harberd and J. Peng (2002). Gibberellin regulates Arabidopsis seed germination via $R G L 2$, a $G A I / R G A$-like gene whose expression is up-regulated following imbibition. Genes Dev., 16:646658.

Li, S.F. (2009). The Arabidopsis MYB5 transcription factor regulates mucilage synthesis, seed coat development, and trichome morphogenesis. Plant Cell., 21: 72-89.

Lin, Z., Y. Hong, M. Yin, C. Li, K. Zhang, D. Grierson (2008). A tomato HD-Zip homeobox protein, LeHB-1, plays an important role in floral organogenesis and ripening. Pl. J., 55: 301-310.

Liu, Y.L., M. Schiff and S.P. DineshKumar (2002). Virus-induced gene silencing in tomato. Pl. J., 31:777-786.

Mandaokar, A. and J. Browse (2009). MYB108 acts together with MYB24 to regulate jasmonate mediated stamen maturation in Arabidopsis. Pl. Physiol., 149: 851-862.

Manning, K., M. Tör, M. Poole, Y. Hong, A.J. Thompson, G.J. King, J.J. Giovannoni and G.B. Seymour (2006). A naturally occurring epigenetic mutation in a gene encoding an SBP-box transcription factor inhibits tomato fruit ripening. Nat. Genet., 38: 948-952.

Martín-Trillo, M., E.G. Grandío, F. Serra, F. Marcel, M.L. Rodríguez-Buey, G. Schmitz, K. Theres, A. Bendahmane, H. Dopazo and P. Cubas (2011). Role of tomato BRANCHED1-like genes in the control of shoot branching. Pl. J., 67: 701-714.

Millar, A.A. and F. Gubler (2005). The Arabidopsis GAMYB-like genes, MYB33 and MYB65, are microRNA-regulated genes that redundantly facilitate anther development. Pl. Cell., 17: 705-721.

Ogata, K., C. Kanei-Ishii, M. Sasaki, H. Hatanaka, A. Nagadoi, M. Enari, H. Nakamura, Y. Nishimura, S. Ishii, and A. Sarai (1996). The cavity in the hydrophobic core of Myb DNAbinding domain is reserved for DNA recognition and trans-activation. Nat. Struct. Biol., 3: 178-187.

Pan, I.L., R. M. Quinn, J.J. Giovannoni, and V.F. Irish (2010). Functional diversification of AGAMOUS lineage genes in regulating tomato flower and fruit development. J. Exp. Bot., 61: 1795-1806.

Paz-Ares, J., D. Ghosal, U. Wienand, P. A. Peterson and H. Saedler (1987). The regulatory c1 locus of Zea mays encodes a protein with homology to myb proto- 
oncogene products and with structural similarities to transcriptional activators. The EMBO J., 6: 3553-3558.

Qi, T., H. Huang, S. Song and D. Xie (2015). Regulation of jasmonate mediated stamen development and seed production by a bHLH-MYB complex in Arabidopsis. Pl. Cell., 27: 1620-1633.

Rivka, B., I. Sobolev, T.E. Eilon, A.G.I. Chmelnitsky, S. Shabtai and E.G. Yehiam (2005). The tomato early fruit specific gene Lefsm1 defines a novel class of plantspecific SANT/MYB domain proteins. Planta, 221:197-211.

Schmitz, G., E. Tillmann, F. Carriero, C. Fiore, F. Cellini and K. Theres (2001). The tomato Blind gene encodes a MYB transcription factor that controls the formation of lateral meristems. PNAS, 99 (2): 1064-1069.

Seymour, G.B, L. Ostergaard, N.H. Chapman, S. Knapp and C. Martin (2013). Fruit development and ripening. Annual Rev. Pl. Biol., 64: 219-241.

Smulders, M.J.M., W. Rus-Kortekaas and L.J.W. Gilissen (1994). Development of polysomaty during differentiation in diploid and tetraploid tomato (Lycopersicon esculentum) plants. P1. Sci., 97: 53-60.

Spoel, S.H., Y. Tada and G.J. Loake (2010). Post-translational protein modification as a tool for transcription reprogramming. New Phytol., 186: 333-339.

Stracke, R., M. Werber and B. Weisshaar (2001). The R2R3-Myb gene family in Arabidopsis thaliana. Curr. Opin. Plant Biol., 4: 447-456.

Sun, X., S.Y. Gong, X.Y. Nie, Y. Li, W. Li, G.Q. Huang and X.B. Li (2015). A R2R3MYB transcription factor that is specifically expressed in cotton (Gossypium hirsutum) fibers affects secondary cell wall biosynthesis and deposition in transgenic Arabidopsis. Physiol. P1., 154: 420-432.

Thomas, S.G. and T.P. Sun (2004). Update on gibberellin signaling. A tale of the tall and the short. P1. Physiol., 135: 668-676.

Tyler, L. (2006). An analysis of potential negative and positive components of the gibberellin signaling pathway in Arabidopsis thaliana. Ph.D. Dissertation (Durham, NC: Duke Univ.).

Tyler, L., T.S.G. Thomas, J. Hu, A. Dill, J.M. Alonso, J.R. Ecker and T.P. Sun (2004). DELLA proteins and gibberellin-regulated seed germination and floral development in Arabidopsis. Pl. Physiol., 135 1008-1019.

Vrebalov, J., D. Ruezinsky, V. Padmanabhan, R. White, D. Medrano, R. Drake, W. Schuch, J.J. Giovannoni (2002). A MADS-box gene necessary for fruit ripening at the tomato ripening-inhibitor (rin) locus. Sci., 296: 343346.

Vrebalov, J., I.L. Pan, A.J. Arroyo, R.M.Quinn, M. Chung, M. Poole, J. Rose, G. Seymour, S. Grandillo and J.J. Giovannoni (2009). Fleshy fruit expansion and ripening are regulated by the tomato SHATTERPROOF gene TAGL1. P1. Cell., 21: 3041-3062.

Wang, H., B. Jones, Z.G. Li, P. Frasse, C. Delalande, F. Regad, S. Chaabouni, A. Latche, J.C. Pech and M. Bouzayen (2005). The tomato Aux/IAA transcription factor IAA9 is involved in fruit development and leaf morphogenesis. Pl. Cell, 17: 2676-2692.

Wen, C.K. and C. Chang (2002). Arabidopsis RGL1 encodes a negative regulator of gibberellin responses. Pl. Cell., 14 87-100.

Whiteside, S.T. and S. Goodbourn (1993). Signal transduction and nuclear targeting: regulation of transcription factor activity by subcellular localisation. J. Cell Sci., 104 (4): 949-55. PMID 8314906.

Xu, R., Y. Wang, H. Zheng, W. Lu, C. Wu, J. Huang and K. Yan (2015). Salt-induced transcription factor MYB74 is regulated by the RNA-directed DNA methylation pathway in Arabidopsis. J. Exp. Bot., 66: 5997-6008.

Yu, E.Y., S.E. Kim, J.H. Kim, J.H. Ko, M.H. Cho, I.K. Chung (2000). Sequence-specific DNA recognition by the Myb-like domain of plant telomeric protein RTBP1. J. Biol. Chem., 275: 24208-24214.

Zhang, Z.B. (2007). Transcription factor AtMYB103 is required for anther development by regulating tapetum development, callose dissolution and exine formation in Arabidopsis. P1. J., 52: 528-538. 


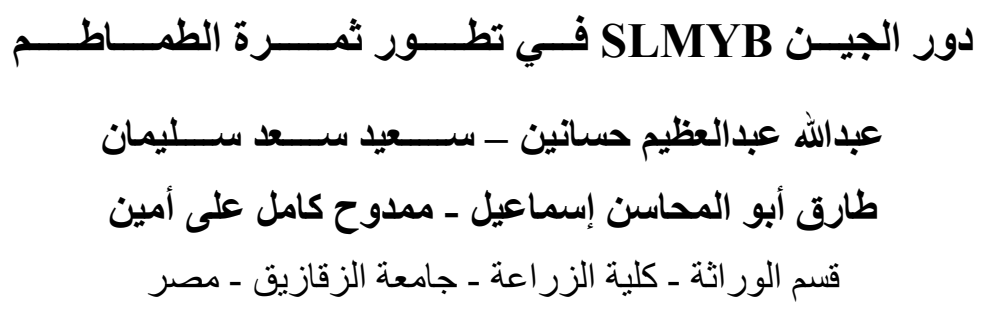

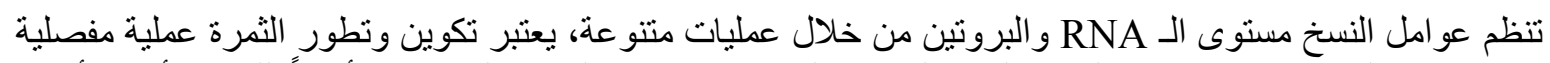

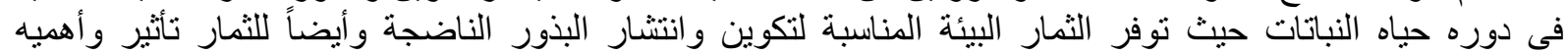

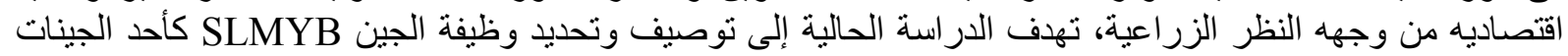

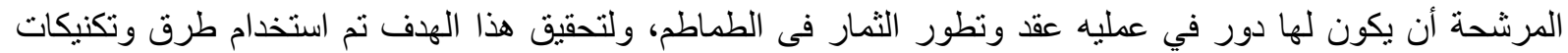

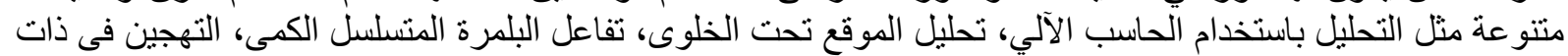

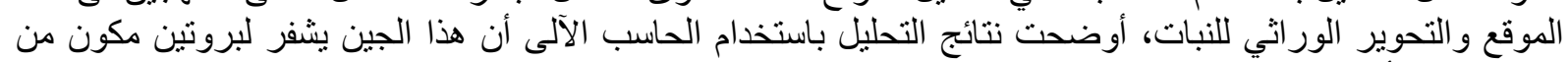

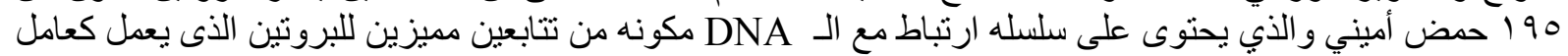

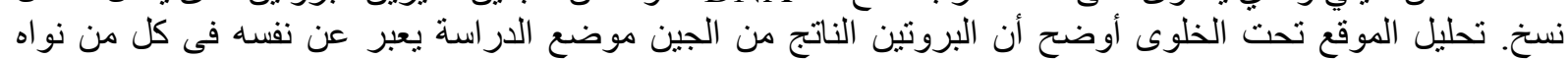

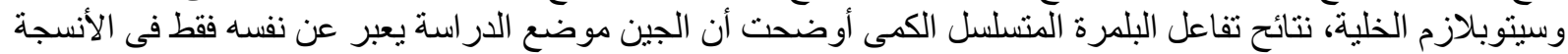

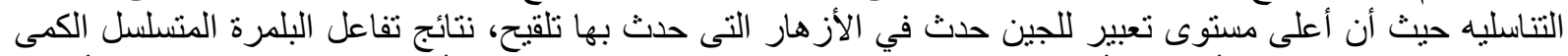

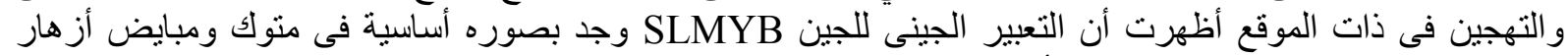

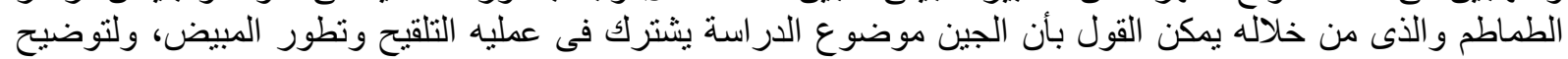

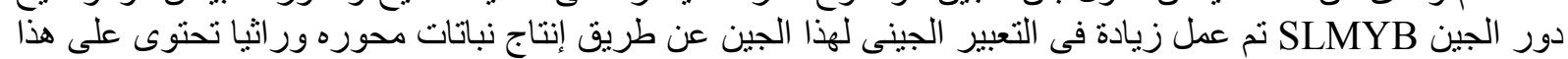

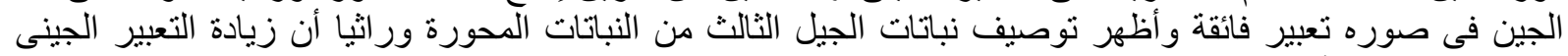

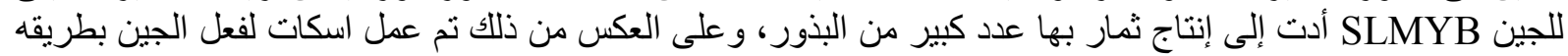

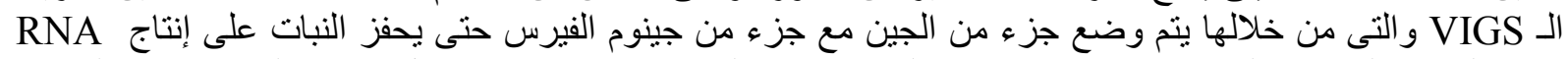

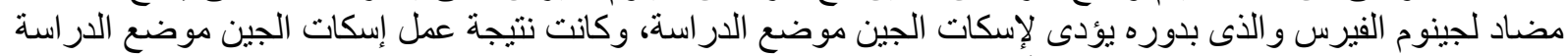

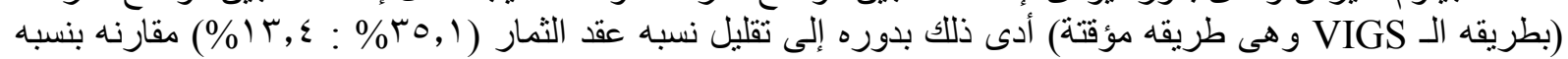

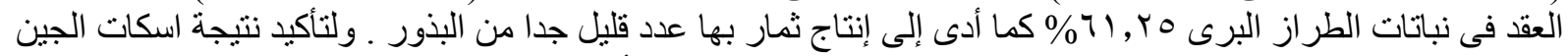

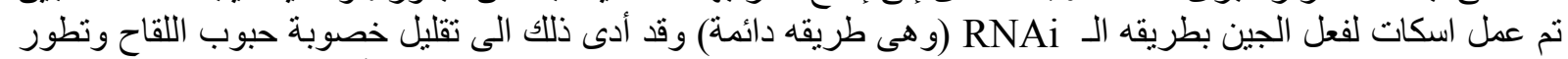

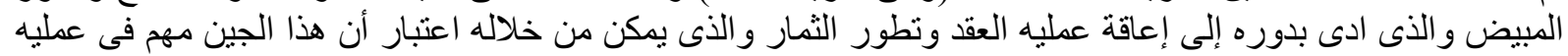
تطور الزهرة وتكوين البذور. 